\title{
ENHANCING STUDENTS' VOCABULARY MASTERY BY APPLYING DICTOGLOSS TECHNIQUE TO THE ELEVENTH GRADE STUDENTS OF SMA DELI MURNI BANDAR BARU IN THE ACADEMIC YEAR OF 2020/2021
}

\author{
Nancy Srimina Br Pinem ${ }^{1}$, Jontra Jusat Pangaribuan², Anna Stasya Prima \\ Sari $^{3}$ \\ Universitas Katolik Santo Thomas Medan, Indonesia \\ Email : jontra_pangaribuan@ust.ac.id
}

\begin{abstract}
This research was primarily conducted to prove that the application of Dictogloss technique could enhance the vocabulary mastery of the eleventh grade students of SMA Deli Murni Bandar Baru Bonaventura Class in the Academic Year of 2020/2021 and to describe their responses towards the application of Dictogloss technique in the process of learning vocabulary mastery. This research is Classroom Action Research which was perfomed in two cycles. Each cycle consisted of four meetings. The quantitative data analysis showed that the students mean score increased continually from 44,16 in pre-test, 59,17 in formative test, and 70,83 in post-test. And the percentage of the students who passed the mastery minimum criteria from pre-test to post-test is $60,39 \%$. The qualitative data analysis showed that the students responses after being taught by using Dictogloss technique. It can be seen from observation sheets and field notes; they felt more enthusiastic and motivated to learn vocabulary mastery after Dictogloss technique was applied. The questionnaire data also showed that students are agree with the application of using Dictogloss technique and found it effective in teaching vocabulary mastery. It is suggested that English teachers using Dictogloss technique as an alternative media in teaching vocabulary to the students in Senior High School in order to enhance their students' vocabulary mastery.
\end{abstract}

Keywords: Vocabulary Mastery, Dictogloss Technique, Classroom Action Research (CAR)

\section{INTRODUCTION}

\subsection{The Background of the Study}

Without vocabulary we cannot communicate with others because vocabulary has an important role when learning languages. In any language teaching vocabulary have a tremendously important role. According to Alqahtani (2015:26) Vocabulary mastery is required to express and to understand other people's sayings. That is the reason why vocabulary is very important in learning a language. If we can enrich our vocabulary in language, it will be easier for us to understand what other people's sayings.

There were many students who have not been able to master the vocabulary especially in English including students of SMA Deli Murni Bandar Baru who would be examined. Writer have implemented internship program in these school. Students at the school are still very lack in vocabulary. Even though they have been studying vocabulary for several years in English. That is the reason of writer to took vocabulary as a skill to be applied in SMA Deli Murni Bandar Baru. 
Students lack of vocabulary because students are lazy to memorize a few words, students did not practice at home because they were not interested in English. So the teacher's role is very influential to enhance students' vocabulary. Teachers must be wise in choosing the method or technique to be used when teaching.

The vocabulary is present as a gate for productive skills to master speaking and writing. This is due vocabulary is an activity information acquisition has an important role in understanding a foreign language. Therefore, teachers must teach vocabulary well to enable students to be able to transform the information properly and correctly in oral and written form.

Actually, if the teacher can be more creative in teaching, this problem can be solved. In this case, the teachers must provide more motivation to students. The teacher stimulates the students' enthusiasm to learn by creating a new atmosphere in the classroom. The teachers should use suitable technique to conduct some activities that make the students feel interested to learn vocabulary.

There are many techniques and methods of language teaching that can be selected for teaching vocabulary, they are: stick figure, puzzle, card game, wall cards, pictures, Dictogloss etc. Therefore, the writer decided to look closely at one of the alternative ways to improve students' vocabulary mastery, that is Dictogloss technique.

Dictogloss is one of techniques that can be used in language teaching and learning process. According to Wajnryb (1990:5) Dictogloss is relatively recent procedure in language teaching. It borrows a little from traditional dictation but in fact is quite distinct from dictation in both procedure and objectives. The basic procedure of Dictogloss is dictation. Dictogloss is different from the traditional dictation in which the teacher read a text of a story slowly and repeatedly two times and the students make a copy or write the vocabulary what the teacher read or say and the last the students translating some of the vocabulary in a small group.

There are some researches that show the effectiveness of Dictogloss. The first was conducted by Wulandari (2017) entitled "The Use of Dictogloss Technique to Improve Students' Speaking Skill at the Second Grade of SMA AlKautsar Bandar Lampung". That research showed that $\mathrm{t}$-value was higher than $\mathrm{t}-$ table $(9.420>2.042)$ and the value of the significant level was $0.00<0.05$. The mean score of posttest (74.40) was higher than the pretest (60.33) and the gain was 14.07. It means that there was a significant difference in the students' speaking skill after being taught using Dictogloss technique.

The the second one was conducted by Yanti (2018) entitled "Applying Dictogloss Strategy to Improve Students' English Writing Achievement”. The result of that research indicates that the Dictogloss strategy could improve students' achievement in writing narrative text, which proven by the result of the tests that showed an increase in score of the experimental class (74.6) is higher than the control class (69.8).

Based on the research findings above, the writer is interested in applying Dictogloss technique to enhance the students' vocabulary mastery. Therefore, the writer was going to conducted a research entitled 'Enhancing Students' Vocabulary Mastery by Applying Dictogloss Technique to the Eleventh Grade Students of SMA Deli Murni Bandar Baru in the Academic Year of 2020/2021". 


\section{REVIEW OF LITERATURE}

\subsection{Vocabulary}

Vocabulary is the main basis needed in learning a language. We cannot communicate to others if we do not have vocabulary in that language. It is imposible for us to make a conversation without mastering the vocabulary of language. Vocabulary is one of language elements that should be learned and taught. It cannot be denied that it will be difficult to master language without understanding a certain number of words. Sakharam (2014:77) states that If one has a large vocabulary then he can read with speed, comprehension and prepare notes on the material studied by him. Vocabulary is required to express meaning and using the receptive (listening \& reading) and productive (speaking \& writing) skills. Mastering vocabulary is very important for the students who learn English as a foreign language. That is why everybody who learns English or a certain language should know the words. The mastery of vocabulary can support them in speaking when they are communicating to people can write and translate the meaning of words when they definite English. If they do not know the meaning of words, they will not be able to speak, write and translate anything English.

According to Elisabeth (2006:2), experiments have shown that vocabulary size is probably the best single index for predicting achievement in nearly all the other language skill. In addition the listening vocabulary is the basis for the development of the other vocabularies. The words that they have heard and understand will be the basis of their speaking, writing and reading. Students will not often use words that they do not understand when speaking or writing. So, the more vocabulary is mastered, the stronger the foundation for speaking or writing in a language.

\subsection{Vocabulary Mastery}

Vocabulary is the first step to be taught before teaching of language. Vocabulary mastery is essential part of English as foreign language. There is no doubt that vocabulary mastery plays an important role in language skills. It gives contribution to the learners to perfume or practice their skill better. Because of the reason, by mastering vocabulary, they will be able to produce so many sentences easily either in spoken or written and to receive word.

According to Elisabeth (2006:6), every individual possesses four types of vocabularies: listening vocabulary, speaking vocabulary, reading vocabulary, writing vocabulary. When we become a speaker, we can arrange our sentences with the vocabulary that we understand. But when we as listener, we have to master a lot of vocabulary, because we don't know what other people will say to us. Maybe he will say words that we don't understand. We might not understand what other people say because of some words we do not understand. Likewise, a person can write with the help of a few words that they understand, but when reading he faces many words. The meaning of words can be understood by the context, but for proper meaning someone must look at the dictionary. For most people, just seeing the meaning in the dictionary once is not enough to remember the word permanently. When reading and there are some words that we do not know, make us guess the meaning of the word, and it will slow us down to read. Therefore we need to master the vocabulary so we can read the text faster and understand the text. 
Language materials consist of words and sentences. Words are to be mastered to get good vocabulary. There are over half a million words listed in the Oxford English Dictionary. Elisabeth (2006:5) states that Students of secondary school who is studying English as a third language (or second language) should master about 275 syntactic structures and about 3.000 words. At present, there are still many students of secondary school who cannot master 3000 vocabulary in English. While said above, to master English at least have to master 3000 vocabulary words. This is what needs to be improved for students to practice more in mastering vocabulary.

\subsection{Teaching Vocabulary}

There is a lot of vocabulary that we must understand in a language. If we lack vocabulary then it will be difficult for us to understand what other people are saying. Although only a few words that we do not understand, but it will be difficult for us to understand the sentence. Teaching vocabulary is an effort to help students master vocabulary. The teacher must be able to make students interested in learning vocabulary, and of course that is not easy. The teacher must have or prepare appropriate techniques for teaching vocabulary, so that it can help students become more understanding and mastering vocabulary. According to Graves (2013:4) one of the ways to help students increase their vocabularies is to teach them individual words. But the vocabulary that students want to achieve is not measurable, so we cannot teach all the words they need to learn. However, the fact that we cannot teach all of the words students need to learn, does not mean that we cannot and should not teach some of them. According to Sakharam (2014:80), "When we teach the vocabulary to SL learners we try to give the meaning in their mother tongue, teach the spelling, meaning in mother tongue, and teach the spelling the forms ( singular/ plural, past/ present etc.in the case of irregular nouns and verbs) and the pronunciation". Teaching vocabulary in that field is certainly not easy. We must have teaching techniques to make them easier for students to understand. Sakharam (2014:80), "There are some techniques of teaching vocabulary:

1. Actual objects or models: At classroom teacher can be taught names of many things by showing actual objects or models.

2. Actions: The meaning of many words can be made clear by performing simple actions in the classroom e.g. walk, using body gestures.

3. Pictures: The use of pictures for teaching vocabulary is quite obvious; every good dictionary makes use of them. Learners can learn any word with the help of suitable picture, e.g. big, eyes, hand, man, woman etc.

4. Blackboard sketches: Quick blackboard sketches may work in teaching vocabulary. Learner's can easily understand the meaning of the word, it will helpful to develop the vocabulary.

5. Verbal Context: There are many abstract words and the meaning of which cannot presented by visual means. Such a technique is creating verbal context with known words, e.g. (a) I like tea more than coffee. I prefer tea to coffee.

6. Illustrative Sentence: An illustrative sentence is very helpful for showing the usage of word, and every good dictionary makes the use of such kind of sentence and use them after the pupils have grasped the general meaning of the word, e.g. accept. (a)The captain of the team accepted refers judgment without protest. 
7. Synonyms: If the learner's can be already known the acceptable synonym, it can be used in a sentence to teach the meaning of the new word, e.g. pretty (a) the girl is a pretty.

8. Antonyms: Antonyms like the synonyms, an antonym can also be used in a sentence by pupil, if it is already known them.

9. Translation and Explanation: These two seem to be the top favorites with teachers. But it will have been clear that they are at least satisfactory means of teaching vocabulary. Translation and explanation in pupil's mother tongue should be attempted only when the other means discussed above have been found inadequate or unnecessarily time consuming."

\subsection{Dictogloss}

Dictogloss is one technique that can be used to teach vocabulary. According to Wajnryb (1990:5) Dictogloss is relatively recent procedure in language teaching. It borrows a little from traditional dictation but in fact is quite distinct from dictation in both procedure and objectives. Dictogloss is almost same with dictors, which different its procedures and objectives. Wajnryb (1990:6) states that Dictogloss is a task-based procedure designed to help language learning students towards a better understanding of how grammar works on the text basis. It is designed to expose where their language learners shortcomings (and needs) are, so that teaching can be directed more precisely towards these areas. In this sense it is eminently learner needs based.

According to Jacobs (2003:14) Dictogloss is classroom research dictation activity where the learner listen to a passage, note down the key words and then work together to create a reconstruct the version text. The task of reconstruction the text in their own words requires the students to consciously focus on their knowledge of the content and the relationship between ideas and words and independent upon small group interaction since the students do not work alone in the reconstruction, but pool their key words and understanding to complete the task.

Based on the above explanation, it can be concluded that the teaching of vocabulary cannot be implemented without careful planning and appropriate. In fact, not all school in Indonesia and is equipped with a language laboratory that does not mean teaching vocabulary should be ignored. With this condition, many activities that can be done to change the function so that language laboratory vocabulary can still be taught well. One way is to apply the Dictogloss.

\subsubsection{Teaching Vocabulary by Applying Dictogloss Technique}

An approach in teaching is a way of looking at teaching and learning. Underlying any language teaching approach is a theoretical view of what language is, and of how it can be learnt. A technique is a way of teaching, guiding and facilitating learning, enabling the learner to learn, setting the condition for learning. As a teacher should know how to teach vocabulary well.

Almost students feel difficult in mastering vocabulary because it is very hard for them to memorize the words. That is why the teacher should use different technique and style in teaching English vocabulary to motivate the learner to enhance their vocabulary and to make them able to speak English properly. One of interesting teaching is Dictogloss technique. Dictogloss is a good way in teaching vocabulary.

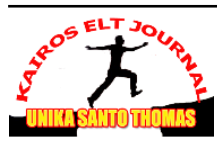




\subsubsection{Procedure of Dictogloss}

According to Wajnryb (1990:5) there are five procedure that may be summarized they are:

1) A short, dense text is read (twice) to the learners at normal speed.

2) As it is being read, the learners jot down familiar words and phrases

3) Working in small groups, the learners pool their battered text and strive to reconstruct a version of the text from their shared resources.

4) Each group of students produce its own reconstructed version, aiming at grammatical accuracy and textual cohesion but not at replicating the original text.

5) The various versions are analysed and compared and the students refine their own text in the light of the shared scrutiny and discussion

\subsubsection{The Aims of Dictogloss}

Wajnryb (1990:6) states that Dictogloss has a number of aims:

1) It aims to provide an opportunity for learners to use their productive grammar in the task of text creation. Learners' linguistic resources are called upon as they pool their fragmented notes and consider the various language options available to them.

2) It aims to encourage learners to find out what they do and do not know about English. This is realized in the attempts to reconstruct the text and in the subsequent analysis of those attempts.

3) It aims to upgrade and refine the learners use of the language through a comprehensive analysis of language option in the correction of the learners' approximate text.

\section{RESEARCH METHOD}

\subsection{Research Design}

This is Classroom Action Research (henceforth, CAR). CAR directs toward an action or cycle of action that a writer wants to take to address situation in the classroom. According to Burns (2010:2) Action research is part of a broad movement that has been going on in education generally for some time. It is related to the ideas of 'reflective practice' and 'the teacher as researcher'. Action research involves taking a self-reflective, critical, and systematic approach to exploring your own teaching contexts. So, in Action research, a teacher becomes an investigator or explorer of his or her personal teaching context, while at the same time being one of the participants in it.

Based on the definition above, the writer could concluded that classroom action research is form of research that applying an idea in a social or educational situation in order to enhancing something to be better, or to get real effect on the situations. In this study, the data were qualitative and quantitative data. In doing this research, the writer would be helped by a collaborator to help defining and exploring certain problems and needs in the classroom. The writer acts as real teacher who taught vocabulary to the students by applying Dictogloss.

\subsection{The Location and Time of the Study}


The study would be conducted at SMA Deli Murni Bandar Baru which is located at Jln. Jamin Ginting Bandar Baru. There were two reasons why the writer chooses the school as the location of the research. They are: 1) based on the preliminary research that was done by the writer, it is needed to enhance the achievement of the eleventh grade students of SMA Deli Murni Bandar Baru in Academic Year of 2020/2021 in enhancing students' vocabulary mastery by applying Dictogloss. 2) based on the writer's knowledge, there is no similar research which has ever been conducted at the school. This research would be conducted in eight meetings excluded pre-test and post-test. Research would be carried out in July 2020.

\subsection{The Subject of the Study}

The subject of the study is the tenth grade students of SMA Deli Murni Bandar Baru in the Academic Year of 2020/2021. The numbers of the students in that class are 24 students, including 17 women and 7 men.

\subsection{The Instruments for Collecting Data}

The instruments which were used in order to collected the data in this research were vocabulary observation sheets, questionnaire, field notes and test.

\subsection{Technique of Data Analysis}

This research used quantitative and qualitative data. Quantitative data is used to analyze student scores; Qualitative data was used to describe the situation during the teaching process. Quantitative data would be analyzed by calculating the vocabulary test scores and qualitative data would be analyzed from observation sheets. To evaluate the students' improvement in vocabulary, the writer gave 10 questions for each cycle. Each question has 10 scores. If all questions were answered correctly it would score 100.

\section{DATA ANALYSIS AND DISCUSSION \\ 4.1 Data Analysis}

There are two kinds of data which were analyzed in this CAR. They are quantitative data and qualitative data. Quantitative data were taken from vocabulary tests, while the qualitative data were taken from observation sheets, field notes and questionnaire.

\subsection{Quantitative Data}

The quantitative data were taken from the results of students, namely pretest, formative test and post-test. Before conducting the treatment, the pre-test was given to measure how well the students' vocabulary mastery. In the last meeting of cycle 1 , the formative test was given to measure the improvement of the students. Then, the post-test was given to the students at the end of the whole cycles to measure the students' improvement after the treatment.

\subsection{The Qualitative Data}

The qualitative data were taken from observation sheets, field notes, and questionnaires.

\subsection{Discussion}

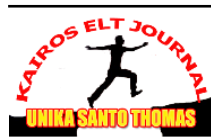


Dictogloss technique was applied to enhance students' vocabulary mastery to the eleventh grade students of SMA Deli Murni Bandar Baru. The enhancement could be seen from the students' mean score the pre-test up to post-test. The students mean score of pre-test is 44,16 , the mean score of formative test is 59,17 and the mean score of post-test is 70,83. Table 4.3 showed that in the percentage of the students who got score. Those score showed that the second cycle was better that the first cycle. Besides that, the enhancement could be seen from the observation sheet, field notes and questionnaire. Most of students were more active and enthusiastic during the process of teaching and learning start from the first to second cycle when the technique was applied.

But when applying this technique, the writer faced into some problems. Some problems that faced by the writer for example, not all students take lessons for various reasons. Because lessons are conducted online, teachers cannot control students to take part in learning. Many of them could not attend the lessons because of the difficult network. Actually, there are about 35 students in the class, but 20 to 25 people take lessons. When filling out the attendance list, many students filled out the attendance list, but did not enter the lesson. Besides that there are also some students who do not have obstacles to attend lessons, but they do not attend lessons. And the writer tries to get him to take lessons by contacting him personally. So at every meeting the writer always contacts students personally to enter learning.

In conclusion, Dictogloss technique is suitable technique to enhance students' vocabulary mastery because this technique gave students a chance to enhance their ability and more active. Even though, the application of this technique required a long time to implement in the classroom. As the result, the students' vocabulary score test increased in both of cycle after being taught with Dictogloss technique and also had good response toward the learning teaching processes through the application of Dictogloss technique.

\section{CONCLUSIONS AND SUGGESTIONS}

\subsection{Conclusions}

After analyzing the data, the writer drew the following conclusion:

1. Dictogloss technique can enhance students' vocabulary mastery. It was found that the students' achievement of vocabulary mastery enhanced from pre-test to post-test after Dictogloss technique was applied. The students' total mean score in pre-test is 44,16, and post-test is 70,83. Meanwhile, the students' score percentage who passed Mastery Minimum Criteria ( Kriteria Ketuntasan Minimum) from pre-test is $0 \%$ and post-test is $37,5 \%$, the students score percentage continuously increased in each test. And the percentages of the students who passed the KKM from pre-test to post test is $37,5 \%$.

2. Based on the analysis of qualitative data, it was found that the students' response towards the use of Dictogloss technique to enhance their vocabulary mastery is very good. They found that Dictogloss technique helped them to enhance their vocabulary mastery.

\subsection{Suggestions}

Based on the research findings, the writer would like to give some suggestions to be considered, as follows:

1. For the English teachers 
In this study, the writer hopes that teachers are motivated to enhance students' achievement by using Dictogloss technique, or with other methods or techniques that make students feel more interested in learning English vocabulary.

2. Students should be active in learning teaching process and should pay attention to the rules how to improve their vocabulary mastery through Dictogloss technique.

3. For other writers

The result of this study is expected to be able to provide other writers valuable information about how to enhance students' vocabulary mastery through Dictogloss technique.

\section{BIBLIOGRAPHY}

Alqahtani, Mofareh. 2015. The Importance of Vocabulary in Language Learning and How to be Taught. International Journal of Teaching and Education, 3(3), 26-29.

Burns, Anne. 2010. Doing Action Research in English Language Teaching: A Guide for Practitioner. New York: Routledge.

Elisabeth, Eva Sundari. 2006. Problems of Continuing Education: Acquisition of English Vocabulary. New Delhi: Discovery Publishing House.

Graves, Michael F. 2013. Teaching Vocabulary to English Language Learners. New York: Teachers College Press.

Latif, Nasrah Kusuma. 2016. The use of Dictogloss Method in Improving the Students' Vocabulary at the Second Grade of SMPN 20 Bulukumba. An Unpublished Sarjana's Thesis, Faculty of Tarabiyah and Teaching Science: Alauddin State Islamic University.

McCharty, Michael. 1990. Language Teaching:Vocabulary. New York: Oxford University Press.

Sakharam, Gore Rajesh. 2014. Teaching Vocabulary in ESL Classroom. An International Peer-Reviewed Open Access Journal, 1(2), 77-81.

Wajnryb, Ruth. 1990. Resource Book for Teachers: Grammar Dictation. New York: Oxford University Press.

Wulandari, Adys Anggun. 2017. The use of Dictogloss Technique to Improve Students' Speaking Skill at the Second Grade of SMA Al-Kautsar Bandar Lampung. An Unpublished Sarjana's Thesis, Faculty of Teacher Training and Education: University of Lampung.

Yanti, Cut Frida. 2018. Applying Dictogloss Strategy to Improve Students' English Writing Achievement. An Unpublished Sarjana's Thesis, Faculty of Education and Teacher Training: Ar-Raniry State Islamic University. 